\title{
COP9 Signalosome Complex Subunit 6
}

National Cancer Institute

\section{Source}

National Cancer Institute. COP9 Signalosome Complex Subunit 6. NCI Thesaurus. Code C124919.

COP9 signalosome complex subunit 6 ( $327 \mathrm{aa}, \sim 36 \mathrm{kDa}$ ) is encoded by the human COPS6 gene. This protein is involved in the mediation of signalosome-dependent cellular processes. 